\title{
Mature ECEC Student Teachers' Perceived Professional Agency during Work Placements
}

\author{
Tuulikki Ukkonen-Mikkola \\ University of Tampere \\ Tampere, Finland
}

\begin{abstract}
This study examines the professional agency (PA) of mature students during accelerated early childhood teacher training at a Finnish university, with a particular focus on how the students perceived PA during work placements. It further examines the supporting and preventing factors affecting the students' sense of agency. Data were analysed using thematic content analysis. The findings show that PA was perceived to be greater during the third placement than during the first. After the third placement and in the practice at the end of their studies, the mature student teachers perceived PA in terms of daily pedagogical practices, community, and motivation. The factors supporting the mature student teachers' sense of PA were earlier qualifications and work experience, a confidential relationship with mentors, guidance practices, and reflection. The findings suggest that while work placements are useful learning environments for promoting the students' sense of PA, universities should nevertheless develop guidance practices and tools for mature students.
\end{abstract}

Keywords: professional agency; early childhood education; teacher training; mature students; work placements

\section{Introduction}

This study examines mature students' experiences of an accelerated early childhood teacher-training programme at a Finnish university. In particular, this study focuses on how mature early childhood education and care (ECEC) student teachers perceive professional agency (PA) during work placements and examines the supporting and preventing factors affecting their sense of agency. This study concentrates on the first and third placements, outlining how PA was perceived and how it changed during these periods. By investigating these time points, we can recognise how the student teachers' sense of PA developed over the whole process of accelerated training.

The subject is timely, because pedagogical work in ECEC has become more challenging. The increasingly complex daily situations and diversity among children and families require the continuous improvement and development of ECEC practices (Urban, 2008).PA is essential for developing work communities 
and changing working practices (Eteläpelto, Vähäsantanen, Hökkä, \& Paloniemi, 2013; 2014). In addition, there has been little research on ECEC teachers and EC student teachers' sense of PA.

People enter new professions in later life for many reasons. Some reasons are economic: for example, the fear of unemployment and very early retirement can be motivations to retrain. Another reason is job dissatisfaction: people may feel that their knowledge and skills are not being used sufficiently in their work, or they have problems in their work communities (McNair \& Watts, 2014). The age at which one is defined as a mature student varies from country to country, and usually the minimum age is around 21 to 25 years (Ross et al., 2002). All the students who participated in the accelerated training described in this study were $25-47$ years old.

Theoretically, this study is based on the principles of PA. The latter refers to the practitioners' capacity to influence their work practices and professional identities. Studies of teachers' PA have shown it to involve negotiating and influencing core pedagogical practices, making decisions, and developing the teaching work (Eteläpelto, Vähäsantanen, \& Hökkä, 2015). Furthermore, social aspects frame the teachers' PA in teaching communities (Eteläpelto et al.,2015; Lasky, 2005). Student teachers' sense of PA is strongly related to the other students and the wider community (Pyhältö, Pietarinen, \& Soini, 2015; Väisänen et al., 2016; Soini, Pyhältö, \& Pietarinen, 2015).

Increasing understanding about PA is important, because several studies have shown that the teacher's PA enables the pupils to develop their own agency (Edwards, 2005; Lipponen \& Kumpulainen, 2011). Therefore, if future teachers are "given an active role in their own studying, they will probably be more likely to promote agency in their future pupils" (Heikkilä, Lonka, Nieminen, \& Niemivirta, 2012, p. 468). In addition, Lipponen \& Kumpulainen (2011) highlight that the way student teachers develop a sense of PA during their studies is crucial to their future skills and abilities to operate as professional agents in their community.

The remainder of this article is arranged as follows: the following section introduces the theoretical concepts of PA, the third section describes mature students as learners, and the fourth section introduces Finnish ECEC training, accelerated training, and placements as the context of the study. In the fifth section, the results are presented, and the discussion and conclusions follow in the sixth section.

\section{Professional agency in the teacher's work and teacher training}

The aim of this study is to investigate how mature EC student teachers perceive professional agency (PA) during work placements. In this section, agency and PA are defined first in a general sense and then from the teachers' and the students' point of view. There has been little research on EC student teachers' PA. In the context of primary schools, by contrast, student teachers' perceived PA is well studied. 
Emirbayer and Mische (1998, p. 970) define agency as follows:

Agency is the temporally constructed engagement by actors of different structural environments - the temporal relational contexts of action - which, through the interplay of habit, imagination, and judgment, both reproduces and transforms those structures in interactive response to the problems posed by changing historical situations.

In particular, Emirbayer and Mische (1998) state that the life-course is important in the agentic process; actors reconstruct the temporal-relational contexts and transform their own values and themselves.

PA is a resource for professional learning, and it can be recognised on both the collective and individual levels of the subject's work (Vähäsantanen et al.,2017). PA exists when the subject's agency is work-related and directed, and when the subject exerts, influences, makes choices, and affects his/her work and/or professional identity (Eteläpelto et al., 2013). Professional identity is constructed through social relationships, and feedback on the actions and it is intertwined with an agency (Edwards, 2015). Hence, a strong sense of PA can help the individual develop a more coherent and flexible identity as a teacher (Ketelaar et al., 2012; Soini et al., 2015).

The teacher's PA is implemented within the classroom and school context in their teaching practices (Vähäsantanen, Saarinen, \& Eteläpelto, 2009). PA "includes influencing and negotiating core pedagogical and instructional practices (including applying new ideas at work), making decisions on one's ways of teaching, and developing one's work' (Eteläpelto et al., 2009, p. 663). The social and material aspects frame the teachers' PA in their work. Aspects of this kind are the curriculum, professional norms, the tasks undertaken, and material resources (Lasky, 2005).

A teacher's professional competence, interests, and work experience are connected to his/her PA (Vähäsantanen et al., 2009). Hence, PA consists of the teacher's motivational, attitudinal, and cognitive resources, in addition to abilities to organise learning in various professional contexts - for example, in the classroom with pupils, and in development work in the professional community. PA is constructed and re-constructed in relation to the object of the activity, the context, and prior learning experiences (Toom et al., 2017; Lipponen \& Kumpulainen, 2011).

When considering the student teacher's sense of PA, the same features can be recognised as when considering the PA of qualified teachers, but with different emphases. The student teachers' sense of PA has a social nature; it is strongly related to the other students and the community. The PA of students can be understood as an approach in which others are experienced as significant resources for learning while the students themselves contribute their personal potential in a collaborative and reciprocal learning process (Hakkarainen, 
Paavola, \& Lipponen, 2004; Soini, Pyhältö, \& Pietarinen,2010). This means that student teachers utilise feedback received from the other students and the teacher, solve problems together via discussions, support others, and are supported themselves (Pyhältö et al., 2015; Väisänen et al., 2016).

The nature of the learning environment - in particular it's emotional and social features - is crucial for the student teachers' PA. A learning environment that promotes a feeling of belonging to a community and active participation supports the student teachers' PA (Lipponen \& Kumpulainen, 2011). Furthermore, the student teachers' sense of PA includes an appreciation of collective efficacy and equality (Pyhältö et al., 2015; Soini et al., 2015; Väisänen et al., 2016).

In addition to the social and communal nature of the student teachers' sense of PA, there are also intellectual, attitudinal, and behavioural features. These features consist of the motivation to learn, intentional actions for promoting school development, and beliefs regarding self-efficacy (Pietarinen et al., 2013; Pyhältö et al., 2015).

In summary, it can be noted that there are several interpretations of PA. The central features of the teachers' PA are individual and collective development work, identity, and motivation. The student teachers' sense of PA in particular has a social nature. Student teachers are ready for reciprocal and communal learning processes with other students and teachers. As mentioned, PA is crucial in the teachers' work, and it is important to investigate how EC student teachers perceive their own sense of PA.

\section{Mature students as learners}

This study examines the perceived PA of mature students during work placements. Mature students are defined in this study as students over 25 years old participating in accelerated ECEC teacher training. The typical features of mature learning are described in this section.

Several theories hold that mature learning is highly motivated, problem-centred, relevance-focused, goal-oriented, and self-directed (Knowles1980; 1992; Isenberg, 2007). The teacher's role in mature students' education is to be a facilitator and collaborator of knowledge (Merriam, 2001).

Nelken (2009) notes that mature students' life experiences affect their learning; they are not 'blank slates'. Mature students' cognitive structures and meaning systems direct their understanding of reality (Mezirow, 2000). Mature learners are active agents in the planning and implementation of their learning, and they value learning based on problem-solving (Knowles, 1980). Transformation is also a part of mature learning. Transformations happen when long-standing beliefs and conceptions are challenged. According to Mezirow (2009, p. 22), "transformative learning transforms problematic frames of reference to make [the student] more inclusive, discriminating, reflective, open, and emotionally able to change." Consequently, mature learners can develop the way they think 
about learning and knowledge, and their epistemological belief can grow from absolute knowledge to active knowledge construction (Peeters et al., 2014).

In addition, critical reflection is an essential part of mature students' learning. Critical reflection can be defined as "active, persistent, and careful consideration of any belief or supposed form of knowledge in light of the grounds that support it and the further conclusion to which it tends."(Dewey, 1993, p. 9). Brookfield (1986) points out that critical thinking is part of personal development and learning. It involves exploring alternatives, challenging assumptions, and developing reflective practices.

Mature students have differing motivations to study to become a teacher. The extrinsic motives include the numerous employment and career opportunities. The intrinsic motives include a personal interest in teaching and professional development, and a desire to share knowledge, work with children, and improve children's lives (Spear, Gould, \& Lee, 2000).

Ross et al. (2002) state that mature students in higher education have different expectations and needs, and they face various challenges compared to younger students. Mature learners may require support to construct their identity as higher education students, since they do not necessarily have a realistic conception of their studies. They may have had several failures in their studies in the past, so they need encouragement and study guidance.

\section{Finnish ECEC teacher training and work placements as the context of the study}

I investigate mature students' experiences of their accelerated university studies, especially how they perceive their PA during work placements. In particular, I concentrate on the first and third placements, which are at the beginning and the end of their studies. The first practice period was in the October of the mature students' first year. The third period was in the October of their second year. It is therefore possible to find out how the mature student teachers' sense of PA changed over the entire accelerated training programme. In this section, I describe Finnish ECEC teacher training, accelerated training, and the principles and practices of the work placement as the context of the study.

In Finland, ECEC teachers study either to bachelor's or master's degree-level at a university, or to bachelor's degree-level at a university of applied science (polytechnic). The programme at universities consists of theory courses and work placements. The theory courses comprise professional early childhood and preschool education studies (60 credits), basic and intermediate studies in education ( 75 credits), and free choice studies ( 25 credits). Students also take studies that provide general learning skills, such as orientation and language studies (20 credits). The research-based training involves approaches to childhood, developmental psychology, general psychology, pedagogy, sociology, play, and the arts. The methods of training include seminars, lectures, and small group exercises. The placements are an essential part of the teachers' training. 
The mature students took part in an accelerated training programme, which enables them to graduate with an educational sciences bachelor's degree in $1 \frac{1 / 2-2}{2}$ years. This full-time programme was funded by special financing from the Finnish Ministry of Education and Culture, and the aim of the programme is to prevent a shortage of ECEC teachers. Most of these mature students had earlier qualifications and work experience. In this programme, the students can complete the early childhood and preschool education studies (60 credits) in 18 months. Most of the students had already completed the basic studies in education ( 25 credits), free choice studies ( 25 credits), and language studies (20 credits) in their earlier studies. Every student formulated a personal study plan at the beginning of the programme.

Placements are crucial for enabling students to develop their professionalism and expertise in ECEC work (Ukkonen-Mikkola \& Turtiainen, 2016). Learning in the workplace is a pedagogical strategy that can be described as a bridge between practice and theory (Coll \& Zegwaard, 2011). For many students, the placements are the first experience of the profession, and students learn the real demands of the profession (Maynes et al., 2015; Pendergast, Garvis, \& Keogh, 2011). Workplaces offer authentic learning opportunities: students learn to work in teams, for example, and they have the opportunity to try out professional roles (Higgs, 2012).

At the university, the placements are systematic, target-oriented, and instructed by a mentor (an ECEC teacher in the field) and a tutor (an instructor or lecturer from the university). Mentors work at the university's ECEC network preschools and are trained in their mentoring roles (Kupila, Ukkonen-Mikkola \& Rantalainen, 2017). The placements are not understood as the final stage of the studies, and therefore they are integrated immediately into study modules from the first year of studies. The placements also offer the mentors and tutors the chance to reflect and develop their own professional skills in ECEC (UkkonenMikkola \& Turtiainen, 2016).

Each placement has the same three-phase structure (see Figure 1). At the university, students work in groups, and each group has its own tutor (a teacher from the university). Before the actual placement is the preparation phase, during which places at ECEC centres are selected, and the mentors are informed and invited to the university to meet the students and tutors. During the placements, students do reflective tasks - for example, writing descriptions of the learning environments and planning, implementing, and evaluating their pedagogical work with children. In addition, the student group has a reflective meeting in the middle of the placement, and the tutor makes a guidance visit to the ECEC centre. After the placement, the students evaluate and reflect on their learning experiences and practices in discussions (in small groups and in one-toone discussions with the tutor) and via written assessment forms. Moodle, an elearning platform, is used in the guidance (Ukkonen-Mikkola \& Turtiainen, 2016). 


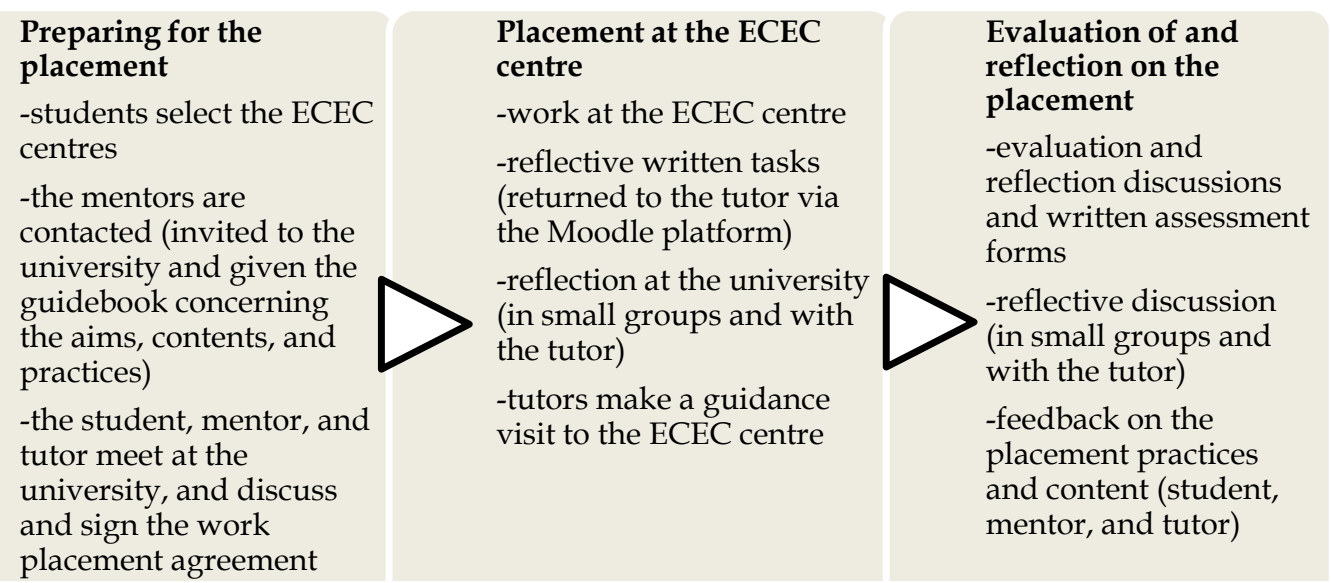

Figure 1. The structure of the work placements process

During the bachelor's studies, there are three placements with different aims and tasks (see Figure 2). The first placement (4 credits) focuses on observing the children and the learning environment. In addition, the learning objectives include the ethics and professional identity of the ECEC teacher. The second placement ( 5 credits) concentrates on the curriculum work and the pedagogy of ECEC. The last placement (6 credits) concentrates on the holistic responsibility of the ECEC teachers' pedagogical work, including cooperation and interaction with the children's parents and the ECEC centre's multi-professional team. During the third period, ECEC teacher students also organise the development process at the ECEC centres. This study investigates the first and third placement periods.

Earlier studies show that work placements have played an important role in developing students' professionalism and PA (Pendergast et al., 2011; UkkonenMikkola \& Turtiainen, 2016; Turnbull, 2005). Placements are essential learning sites for the students' later professional development, and the process of acquiring expertise can begin in the course of these practical periods (Hagger et al., 2008). During this early period, the construction of professional identity and growth into the future role as a teacher begins (Kupila et al., 2013; UkkonenMikkola \& Turtiainen, 2016).

Students highlight the role of the mentor in supporting their learning during the placements. Hence, it is important that the placements are guided by motivated and trained mentors (Leshem, 2012; Kupila, Ukkonen-Mikkola, \& Rantalainen, 2017; Ukkonen-Mikkola \& Turtiainen, 2016). In addition, Turnbull (2005) has highlighted the importance of the mentoring teachers and a welcoming learning environment in supporting the students' PA. Furthermore, continuous professional development for mentoring teachers is important to ensure they are capable of instructing the students. 


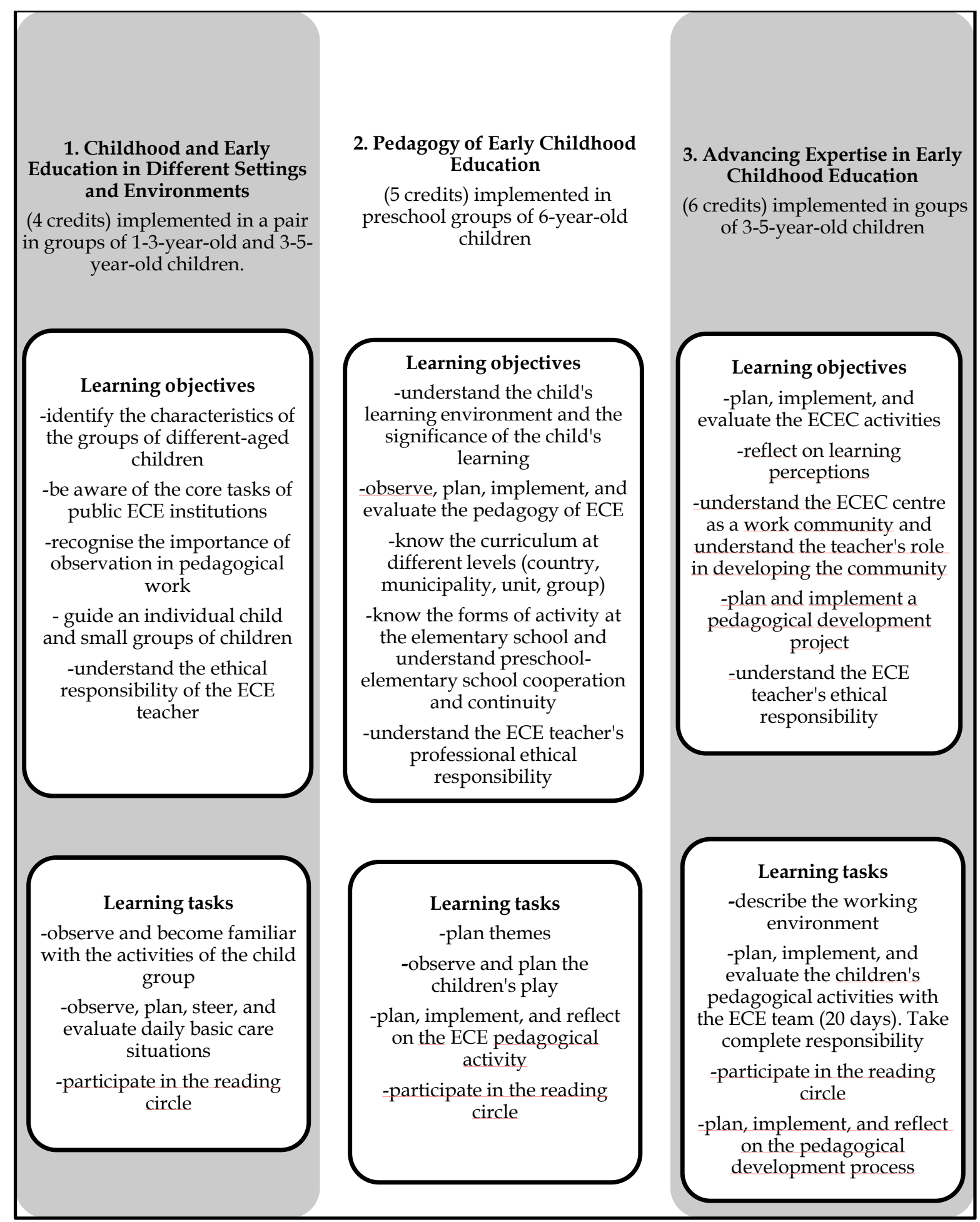

Figure 2. Objectives and tasks of the work placements.

Kaldi (2009) states that mature student teachers can experience feelings of insecurity and conflict at the beginning of placements. Combining theory with practice, general classroom management, presentation, and discipline issues were all considered challenging. Nevertheless, work experience and discussions with other mature students have supported the students in resolving these problems. Despite these challenges at the beginning, mature student teachers 
quickly gain confidence during the placements, and they are even ready to cope with the difficulties they encounter with pupils.

\section{Research questions and methods}

This qualitative study focused on mature students' experiences of an accelerated ECEC teacher-training programme. In particular, the purpose of this study was to find out how mature ECEC student teachers perceive PA during work placements. In addition, this study examined the supporting and preventing factors affecting mature student teachers sense of agency. The study was implemented during accelerated ECEC teacher training at a Finnish university.

\section{Research questions}

The research questions are summarised as follows:

1. How do mature EC student teachers perceive their professional agency during their first and third placements?

2. What are the supporting and preventing factors affecting the student's sense of agency during the first and third placements?

\section{Data collection}

The data were collected from seven mature students participating in the accelerated ECEC teacher-training programme. The age of the mature students varied from 25 years to 47 years. Five of these students had earlier work experience. The educational background of the informants was varied - it included vocational, polytechnic, and university qualifications. Two of the informants had qualifications and experience in ECEC work (Anna and Laura). Three of the informants (Sarah, Helen, and Jenny) had qualifications and work experience from other careers. In the research group, two students had completed upper high school (Sofia and Jane) and had some educational studies and work experience.

The informants worked together in a small group during the work placement process (see Figure 1). The data consist of narrative writings $(n=14)$, portfolios $(n=7)$, pedagogical diaries $(n=7)$, a focus group interview, and individual interviews $(n=5)$. The first set of narrative writings $(n=7)$ and portfolios $(n=7)$ were collected after the first placement, and the second set of narrative writings $(n=7)$ and pedagogical diaries $(n=7)$ were collected after the third placement. The writing sessions were part of the reflective practices after the placements (see Figure1). The interviews were recorded and transcribed verbatim.

The various data revealed versatile approaches to the sense of PA. In the portfolios (54 pages) and diaries (83 pages), the students described and reflected on the ECEC communities and their own pedagogical practices. In the narrative writings, students reflected on their experiences of the placement and their relationship with their mentors (24 pages). The question topic of the narrative writings was 'How did you experience the work placement as a mature student?' The purpose of the focus group interview was to establish common meaning-making regarding the differences between the first and third placements (6 pages). The questions were 'Was your relationship with your 
mentor different in this third placement compared to the first placement?', 'How did you experience the guidance and feedback you received?', 'How did you perceive your PA during the placements?', and 'What do you think about your forthcoming work as an early childhood education expert?' The aim of the individual interviews was to deepen understanding of the significance of life history in terms of the students' PA (14 pages). The question asked was 'How has you previous training, profession, and work history supported or prevented the development of your PA during your work placements?' The total data amounted to 181 pages.

Table 1. Data collection

\begin{tabular}{|l|l|}
\hline $\begin{array}{l}\text { Data collected after the first placement (in the } \\
\text { November of the first year) }\end{array}$ & $\begin{array}{l}\text { Data collected after third placement (in the } \\
\text { November of the second year) }\end{array}$ \\
\hline $\begin{array}{l}\text { 7 narrative writings (11 pages) } \\
\text {-experiences of the placement and the } \\
\text { relationship with the mentor }\end{array}$ & $\begin{array}{l}\text { 7narrative writings (13 pages) } \\
\text {-experiences of the placement and the } \\
\text { relationship with the mentor } \\
7 \text { pedagogical diaries (83 pages) } \\
\text {-descriptions of and reflections on the ECEC } \\
\text { communities and the students pedagogical } \\
\text { practices } \\
\text { 1 focus group interview (6 pages) } \\
\text {-the differences between the first and third } \\
\text { placement }\end{array}$ \\
\hline $\begin{array}{l}\text {-descriptions of and reflections on the ECEC } \\
\text { communities and the students' pedagogical } \\
\text { practices }\end{array}$ & $\begin{array}{l}\text {-the influence of the students' life history on } \\
\text { their PA }\end{array}$ \\
\hline
\end{tabular}

\section{Analysis}

The qualitative data were examined using content analysis. In qualitative research, each participant's personal experiences form its own truth, and the aim of the analysis is to find common and consistent experiences (Buchbinder, 2011). Content analysis is a method for categorising data from a systematic perspective and generalising the studied phenomenon. Through content analysis, it is possible to focus on the essential core of the data (Hsieh \& Shannon, 2005).

In the data analysis, the diaries, portfolios, writings, and interviews were read several times side by side in order to construct an overall view of the students' experiences and perceptions. After that, the data were reduced, coded, categorised, and classified (see Holloway, 2011; Ryan \& Bernard, 2000). With regard to the first question, the analysis was theory driven. Previous theoretical conceptions of PA (teaching practice, the ECEC community, identity, and motivation) guided the process of finding common themes in the students' experiences (see Braun \& Clarke, 2006). When analysing the data in relation to the second research question, the analysis was more abductive: previous theoretical notions partly guided the analysis, but new themes were also created inductively, in a 'bottom-up' way (see Cohen, Manion, \& Morrison, 2007).

Data credibility and the trustworthiness of the findings were considered: many kinds of data (the original portfolios, narrative writings, pedagogical diaries, and interviews) were used. The different methods of data collection and the various types of samples ensure the validity of the findings through 
triangulation (Flick, 2014). In addition, open and exact descriptions of the data gathering and analysis are provided, and many authentic quotations from the data are used later in this article (see Ryan \& Bernard, 2000). All types of data are given equal value, and the quotations in the results section are taken from all types of data.

The study was carried out in accordance with good research ethics. The research participants were informed of the issues related to the objectives and implementation of the study, and of the data management practices employed. Permission to use the portfolios, narrative writings, pedagogical diaries, and interviews as research data was requested from every informant, and a promise of the informants' anonymity was given. Participation in the study was voluntary. The data were analysed after the students had been assigned a final grade and qualified as ECEC teachers. The participants' names have been changed in the quotations. In addition, the name of the university where the study was implemented has been withheld.

\section{Findings}

The findings are introduced in the order of the aforementioned research questions. I first introduce how the mature student teachers perceived their PA during the work placements. I then elaborate on the supporting and preventing factors affecting the students' sense of PA during the work placements. The findings have been enhanced with quotes from the original portfolios, narrative writings, pedagogical diaries, and interviews.

\section{Perceived professional agency during work placements}

The mature student teachers perceived professional agency in teaching practices, ECEC communities, identity, and motivation (see Table 2).

Table 2. Mature student teachers' perceived professional agency during the first and third placements

\begin{tabular}{|c|c|c|}
\hline & FIRST PLACEMENT & THIRD PLACEMENT \\
\hline $\begin{array}{l}\text { Perceived professional } \\
\text { agency in teaching practices }\end{array}$ & $\begin{array}{l}\text { Pedagogical } \\
\text { implemented } \\
\text { mentors }\end{array}$ & $\begin{array}{l}\text { Students developed their } \\
\text { pedagogy in personal ways }\end{array}$ \\
\hline $\begin{array}{l}\text { Perceived professional } \\
\text { agency in the ECEC } \\
\text { community }\end{array}$ & $\begin{array}{ll}\text { Misunderstandings } & \text { and } \\
\text { difficulties in interaction } & \end{array}$ & $\begin{array}{l}\text { Professional discussions, } \\
\text { membership of the team }\end{array}$ \\
\hline $\begin{array}{l}\text { Perceived professional } \\
\text { agency in identity }\end{array}$ & Challenging & Contradictory \\
\hline $\begin{array}{l}\text { Perceived professional } \\
\text { agency in motivation }\end{array}$ & Insecurity, confusion & Increased motivation \\
\hline
\end{tabular}

\section{Perceived professional agency in teaching practices}

At the beginning of the first placement, the mature students mainly observed the pedagogical practices and the work of the mentor and the whole team. Students implemented the pedagogy mostly in the same ways as they had seen the kindergarten teachers do. They were also critical and considered alternatives of how to work, which can be recognised from the extract below: 
The ECEC centre as a workplace has its own nature. It is important to know the practices. It is also good to observe the other educators and adopt (or not!) the model of their practices. (Sarah, portfolio)

During the third placement, some mature students discovered how independent and creative the work of ECEC teachers can be. They felt released from the guidance and the tasks, and developed their pedagogy in their own way. They further felt that they had more freedom and space for their own ideas and personal pedagogical decisions. This feeling of freedom and sense of PA can be surmised from the following quotations:

I realised that I really can plan and implement action for children in my own personal way. It was a very liberating feeling. (Jenny, focus group interview)

The focus of the weekly meeting was the new core curriculum for early childhood education and gender-sensitive education. I'm very enthusiastic - it's such an interesting topic, and it can be combined in my own work. (Helen, pedagogical diary)

\section{The meaning of community for the student teachers' sense of professional agency}

During the third placement, the students felt that their position in the working community had changed. During the first placement, some mature students had unpleasant experiences. Some were uncertain about their position, especially when working with the educator teams. Sometimes there were misunderstandings concerning the assignment of tasks. The next extract describes this kind of situation, and it also reveals the uncertainty of the student:

My mentor asked me to help one child to dress, then suddenly a nursery nurse came and did it. I was very embarrassed. Still, I did not have the courage to tell my mentor about this situation. (Jane, focus group interview)

During the third placement, the students took part in professional discussions at the ECEC centres. Students described that they had in-depth and equal discussions with the educators and the teams. These feelings of increasing agency can be recognised in the following extract:

I feel that the working community involved me in the discussions and respected my ideas. (Sarah, narrative writings)

\section{Missing identity during practice periods}

Identity is closely related to a sense of PA. The identity of teachers as ECEC experts turned out to be challenging for the mature student teachers during both placements. The students felt that the identity and expertise of their mentor teachers was unclear and that the teacher's position in the community varied according to each ECEC centre's organisational culture. This contradictory identity was described as being challenging: 
During my third placement period, the expert identity of the ECEC teacher remained a mystery to me. The basic situations and routines override important professional practices, such as multi-professional cooperation and interaction, discussion with the parents, and the evaluation of the children. (Jenny, pedagogical diary)

Hence, the mature students found working in real environments very useful for their identity, as mentioned in one portfolio:

I can't imagine how I could do this work with children as a teacher without these real situations and experiences in day care centres. (Laura, portfolio)

\section{Mature student teachers' variable motivations}

Motivation is part of the student teachers' sense of PA. Before and during the first placement, some students who had no earlier experience of ECEC were confused and even critical of ECEC work. This can be interpreted in the following extract:

Our ECEC system takes care of children but somethings are missing - the joy between the adult and children, love, and a sense of community. I am not sure if this will be the right place for me. (Sarah, portfolio)

Before and during the third placement, all the students were motivated and eager to learn. They had more theoretical knowledge and practical experience of the profession, and they were more confident about ECEC work. This motivated attitude is expressed in the next extract:

I was excited about this work placement period, as I would face new challenges and develop my professionalism as an ECEC teacher. (Helen, pedagogical diary)

\section{Factors that support or prevent the students' sense of professional agency}

The factors affecting the sense of PA during the placements are revealed in this section. The main themes found in the data were earlier qualifications and work experience, the mentoring relationship, guidance practices and tools, and reflective practices. All of these factors were considered to be both preventing and supporting in developing the students' sense of PA.

Table 3. Factors preventing or supporting the students' sense of professional agency

\begin{tabular}{|l|l|l|}
\hline $\begin{array}{l}\text { Earlier qualifications } \\
\text { and work experience }\end{array}$ & $\begin{array}{l}\text { Preventing for students who had } \\
\text { other qualifications; } \\
\text { Supporting for students with an } \\
\text { ECEC qualification }\end{array}$ & $\begin{array}{l}\text { Experience and maturity were } \\
\text { experienced as supporting factors }\end{array}$ \\
\hline $\begin{array}{l}\text { Mentoring } \\
\text { relationship }\end{array}$ & $\begin{array}{l}\text { Preventing for mature students } \\
\text { who did not get guidance from } \\
\text { young mentors; } \\
\text { Supporting: guidance needed in } \\
\text { daily practices }\end{array}$ & $\begin{array}{l}\text { Supporting: discussion needed } \\
\text { concerning the philosophical } \\
\text { principles of ECEC }\end{array}$ \\
\hline
\end{tabular}




\begin{tabular}{|l|l|l|}
\hline $\begin{array}{l}\text { Guidance practices } \\
\text { and tools }\end{array}$ & $\begin{array}{l}\text { Supporting in helping the student } \\
\text { pay attention to the essential } \\
\text { features }\end{array}$ & $\begin{array}{l}\text { Supporting, but potentially } \\
\text { restrictive and laborious }\end{array}$ \\
\hline Reflective practices & A supporting resource & A supporting resource \\
\hline
\end{tabular}

Earlier life-course as a preventing or supporting factor for a sense of professional agency

Earlier qualifications and work experience can have both a preventing and a supporting effect on the students' sense of PA. Students who had previous qualifications and work experience in the field of ECEC thought that their earlier experience was very useful. They found that they had the opportunity to develop their professionalism from the beginning of the training, as the following quotation confirms:

I could reflect on my experiences using theory. The other students without experience with the children didn't acquire practical knowledge until the first placement. (Anna, interview)

The students with previous qualifications and work experience from other fields thought that they had some established habits and skills that were very difficult to get rid of. These practices can come from earlier professions and may even inhibit their agency and professional growth, as the next extract shows:

In the first placement, I paid attention to organisational operations, because I have earlier worked as a project coordinator and systems expert. My attitude was maybe wrong. (Sarah, interview)

During the third placement, these differences decreased. As the next quotation confirms, the students felt that their experience and maturity supported their sense of PA:

My own experience was minor, but even the smallest things I know helped me to reach the goals of the last placement period. (Sofia,narrative writing)

\section{Meaningful and changing relationships with the mentor}

The students stated that the relationship with the mentor was very important for their sense of PA. During both placements, the students thought it very important to discuss the practices of the ECEC centre with the mentor. The students expected a lot of guidance. During the first period, the discussions were practical, but during the third period, the discussions were more philosophical, concerning the children and conceptions of learning. Most of the students were satisfied with the mentoring, but some problems can be identified in both the students' and mentors' responses concerning the guidance. Some students felt that because they were older, the mentors supposed that they knew more about early childhood education practices than the younger students did. The students thought that because they were older than the mentors were, the mentors were afraid to give feedback and even tried to avoid discussions. The students also thought that as adults, they were very motivated and eager - maybe too eager to learn. The next extract highlights the significance of the age difference between the student and mentor: 
All the workers were so young. We got guidance when we demanded it. I felt that even the mentor was frightened by the situation. She went out with some children and left me inside. (Sarah, focus group interview)

\section{Supporting guidance practices}

The guidance practices and tools (tasks and reports) during the placements also played both promoting and preventing roles in developing the students' sense of PA. The tasks (portfolios and diaries) were considered to support the students in paying attention to the essential features of ECEC work. The reading circle was considered a useful method of combining theory and practice. However, some students felt that the tasks and reports took on a restrictive role and required too much routine work during the third placement.

I would like to write a more creative diary: the tasks given were useless and too laborious. (Helen, narrative writing)

\section{Reflective practices as a resource}

Reflections with the mentor and other students were considered a resource for the students' sense of PA during both placements. The students had many opportunities to reflect on their experiences. The first placement was implemented in pairs, and this arrangement was considered to support reflection. Other opportunities for reflection included meetings with other students and the tutor at the university during and after the placements. In addition, report writing and combining theory with practice supported the students' reflective learning:

Over the whole placement period, I reflected on my own practices and those of my fellow students. This helped me to analyse new and strange situations. When I wrote the report and reflected on the placement, I felt that things opened up to me better. (Laura, narrative writing)

\section{Discussion}

The aim of this study was to investigate how mature early childhood education and care (ECEC) teacher students perceived professional agency (PA) and to uncover the supporting and preventing factors affecting their sense of PA during work placements. The findings show that the mature students believed that their PA increased as their studies progressed. The student teachers reported growth in their PA in teaching practices, their position in the ECEC community, and their identity and motivation. In addition, the supporting and preventing factors affecting the sense of PA during the placements include earlier qualifications and work experience, the mentoring relationship, guidance practices and tools, and reflective practices.

The mature students' perceived agency increased over the final placement: they found their own way to teach. This confirms Kaldi's (2009) finding that mature student teachers find confidence in their work quite easily. The findings of this study indicate that a sense of community and collective efficacy play a significant role in mature students' sense of PA. This result supports earlier 
studies by Pyhältö et al. (2015), Väisänen et al. (2016), and Soini et al. (2015). Lipponen and Kumpulainen (2011) also highlight the importance of the community in terms of students' sense of PA. In addition, the mature students were critical when observing the pedagogical practices of ECEC teachers: this critical thinking and exploration of alternatives is characteristic of mature learning (Brookfield, 1986). Influencing one's work and making choices are also a part of PA (Eteläpelto et al., 2013).

The students considered the work placements essential for the development of their professional identity, even if the experiences of the ECEC teachers' identities were contradictory. This finding can be related to the general diversity of the ECEC centres' multi-professional working cultures (see Karila \& Kinos, 2012; Urban, 2008). Especially at the end of the ECEC studies, the students were motivated, and motivation is typical of mature students' learning (see Knowles 1980, 1992). Pyhältö et al. (2015) concur that student teachers' PA involves the motivation to learn.

According to the findings, the mature students' earlier qualifications and work experience had a significant effect on their sense of PA. Especially at the beginning of the studies, the previous qualifications and work experience even restricted the students' sense of PA. The result confirms Nelken's (2009) idea that mature students are not 'blank slates'; previous life experiences affect their learning. In particular, Emirbayer and Mische (1998) emphasise the importance of the life-course in the agentic process. The differences between those with previous ECEC experience and those who had none seemed to decrease during the final placement. Transformative learning occurred between these placements, which means the students' beliefs and conceptions were able to change (see Mezirow, 2009).

A successful mentoring relationship was considered an important resource to support the students' sense of PA during both placements (see UkkonenMikkola \& Turtiainen, 2016). The mentoring relationship changed during the studies, and on the third placement, the students sought out more philosophical and principled discussions. Some mature students found the age difference problematic; they reported that they did not get enough guidance because they were older than their mentors. Turnbull (2005) points out that students should be understood as future professional colleagues; they should be provided with feedback and have meaningful working relationships with the mentor and other staff. Ross et al. (2002) add that mature students need support and guidance because they may have experienced failure in their past studies.

The guidance practices and tools were regarded as supportive, particularly at the beginning of the studies. However, when the students had more expertise, they found the guidance practices and tools restrictive. Mature students can require more freedom and opportunities for self-direction and active learning based on problem-solving (see Knowles, 1980). Reflective practices were considered a resource supporting the development of PA during both placements. Brookfield (1986) found that mature students have strong reflection 
skills. In the earlier studies, reflection with the other students in particular was found to support the students' sense of PA (Pyhältö et al., 2015; Lipponen \& Kumpulainen, 2011).

\section{Conclusions}

This study revealed that work placements are important for the students' sense of PA. As a pedagogical method, the placements mainly supported the mature students' motivational and reflective style of learning. PA and identity are intertwined (see Edwards, 2017). This study indicated, that the unclear identity of ECEC teachers and the whole ECEC workforce is challenging in work communities. Ambiguity concerning the identities and working focus of the ECEC professionals could be discussed and clarified in co-operation with the ECEC researchers, teachers, professionals and administrators. This would help to identify and enable the PA of all ECEC professionals.

The findings of this study showed, that mature students are ready to take more responsibility for their learning during the third placement. The findings also indicated, that even though mature students are experienced and skilled they nevertheless need a lot of support and encouragement. These are significant findings for the university, and it raises the challenge of developing practices for the mature students' placements. It should be possible to take into account the mature students' individual life-course, needs, and strengths when planning the placement process.

In many countries, including Finland, numerous regulatory and pedagogical reforms have been undertaken to develop ECEC practices (see Miller \& Cable, 2008). In this changing context, it is remarkable that the ECEC teachers have professional agency - for example, the ability to develop their own professional practices and the ECEC community as a whole. In addition, through teachers PA it is possible to enhance children's participation and agency. (see Edwards, 2005; Lipponen \& Kumpulainen, 2011).

At the moment, there is a lack of qualified ECEC teachers in several countries, also in Finland. It is in both the students' and the field's interests that experienced and motivated mature students graduate and are employed at ECEC centres. These positive experiences of teachers' employment encourage universities to offer accelerated trainings to ECEC teachers and also in other academic fields. These ideas align the consideration of learning as a lifelong process, which emphasizes the possibilities to learn new competencies, skills and knowledge over the life course (see Quedler \& Lamb, 2016).

There are some limitations concerning the validity of this study. The informant group was limited, with only seven mature students' experiences being investigated. In addition, the variables related to the mature students' life-course and personal lives may have affected the experiences of the work placements and hence their sense of PA. Furthermore, the data were collected during their 
studies at the university. The informants and researchers' relationship can affect the objectivity and validity of the study (see Atkins \& Wallace, 2012).

In further studies, it would be interesting to investigate how the qualified mature students experience their PA as novice ECEC teachers. Furthermore, studies concerning mature students' experiences of the entire ECEC teacher-training programme and their subsequent sense of PA would be valuable.

\section{References}

Atkins, L., \& Wallace, S. (2012). Qualitative Research in Education. London: SAGE.

Braun, V., \& Clarke, V. (2006). Using thematic analysis in psychology. Qualitative Research in Psychology, 3(2), 77-101. doi:10.1191/1478088706qp063oa

Brookfield, S. (1986). Understanding and facilitating adult learning. San Francisco: Jossey-Bass.

Buchbinder, E. (2011). Beyond checking. Experiences of the validation interview. Qualitative Social Work, 10(1), 106-122. doi:10.1177/1473325010370189

Cohen, L., Manion, L., \& Morrison, K., (2007). Research methods in education. $6^{\text {thed. }}$ London: Routledge.

Dewey, J. (1993). How we think: A restatement of the relation of reflective thinking the educative process. New York: D.C. Heath and Company.

Edwards, A. (2015) Recognising and realising teachers' professional agency, Teachers and Teaching, 21(6), 779-784, doi:10.1080/13540602.2015.1044333

Edwards, A. (2005). Relational agency: Learning to be a resourceful practitioner. International Journal of Educational Research, 43(3), 168-182. doi:10.1016/j.ijer.2006.06.010

Emirbayer, M., \& Mische, A. (1998). What Is Agency? American Journal of Sociology, 103(4), 962-1023. doi:/10.1086/231294

Eteläpelto, A., Vähäsantanen, K., \& Hökkä, P. (2015). How do novice teachers in Finland perceive their professional agency? Teachers and Teaching, 21(6), 660-680. doi:10.1080/13540602.2015.1044327

Eteläpelto, A.,Vähäsantanen, K., Hökkä, \& Paloniemi, S. (2013). What is agency? Conceptualizing professional agency at work. Educational Research Review, 10, 4565. doi:10.1016/j.edurev.2013.05.001

Eteläpelto, A., Vähäsantanen, K, Hökkä, \&Paloniemi, S. (2014). Identity and agency in professional learning. In S. Billett, C. Harteis, and H. Gruber (Eds.), International handbook of research in professional and practice-based learning (pp. 645-672). Dordrecht: Springer.

Flick, U. (2004). Triangulation in qualitative research. In U. Flick, E, Kardoff, \& I. Steinke (Eds.), Companion to Qualitative Research (pp. 178-183). London: Sage.

Goodson, I. F., \& Gill, S. R., (2011). Narrative pedagogy. Life history and learning. New York, NY: Peter Lang.

Hagger, H., Burn, K., Mutton, T., \& Brindley, S. (2008) Practice makes perfect? Learning to learn as a teacher, Oxford Review of Education, 34(2), 159-178, doi:10.1080/03054980701614978

Hakkarainen, K. Paavola, S., \& Lipponen, L. (2004). From communities of practice to innovative knowledge communities. Lifelong Learning in Europe, 9(2), 74-83. 
Heikkilä, A., Lonka, K., Nieminen, J., \& Niemivirta, M. (2012). Relations between teacher students' approaches to learning, cognitive and attributional strategies, wellbeing, and study success. Higher Education, 64(4), 455-471. Doi:10.1007/s10734012-9504-9

Higgs, J., (2012). Practice-based education pedagogy: Situated, capability-development, relationship practice(s). In J. Higgs, R. Barnett, S. Billett, M. Hutchings, and F. Trede (Eds.), Practice-based education: Perspectives and strategies (pp. 71-81). Rotterdam: Sense.

Holloway, I. (2011). Being a qualitative researcher. Qualitative Health Research, 21(7), 968975. doi: 10.1177/1049732310395607

Hsieh, H. F., \& Shannon, S. E. (2005). Three approaches to qualitative content analysis. Qualitative health research, 15(9), 1277-1288. doi:10.1177/1049732305276687

Isenberg, S., (2007). Applying andragogical principles to internet learning. Youngstown, NY: Cambria Press.

Kaldi, S. (2009). Mature student teachers in initial teacher education in Greece: personal and academic identities, European Journal of Teacher Education, 32 (1), 35-49. doi:10.1080/02619760802553014

Karila, K., \& Kinos, J. (2012). Acting as a Professional in a Finnish Early Childhood Education Context. In L. Miller, C. Dalli, and M. Urban (Eds.), Early childhood grows up. Towards a critical ecology of the profession (pp. 55-69). London: Springer.

Ketelaar, E., Beijaard, D., Boshuizenc, H., \& Den Brok, P. (2012). Teachers' positioning towards an educational innovation in the light of ownership, sense making and agency. Teaching and Teacher Education, 28(2), 273-282. doi:10.1016/j.tate.2011.10.004

Knowles, M., (1980). The modern practice of adult education. 3rd ed. New York: Cambridge University Press.

Knowles, M., (1992). The adult learner: a neglected species. 4th ed. Houston, TX: Gulf.

Kupila, P., Lääperi, T., Ahlqvist, T., \& Koivisto, P. (2013). Mentoring professionals in early childhood education and care - "How to become a mentor?" Paper presented at the annual meeting for the annual conference of the Finnish educational research association [Kasvatustieteenpäivät], Jyväskylä.

Kupila, P., Ukkonen-Mikkola, T. \& Rantala, K. (2017). Interpretations of mentoring during the mentor training. Australian Teacher Education, 38(10), 36-49. doi:ro.ecu.edu.au/ajte/vol42/iss10/3/

Lasky, S. (2005). A sociocultural approach to understanding teacher identity, agency and professional vulnerability in a context of secondary school reform. Teaching and Teacher Education, 21, 899-916. doi:10.1016/j.tate.2005.06.003

Leshem, S. (2012). The many faces of mentor-mentee relationships in a pre-service teacher education programme. Creative Education, 3(4), 413-421. doi:10.4236/ce.2012.34065

Lipponen, L., \& Kumpulainen, K. (2011). Acting as accountable authors: Creatinginteractional spaces for agency work in teacher education. Teaching and TeacherEducation, 27(5), 812-819. doi:10.1016/j.tate.2011.01.001

Maynes, N., Mottonen, A-L., Sharpe, G., \& Curwen, T. (2015). A Comparative examination of teacher candidates' professional practicum experiences in two program models. International Journal of Learning, Teaching and Educational Research. 11(1), 36-52. 
Merriam, S. B., (2001). Andragogy and Self-Directed Learning: Pillars of Adult Learning Theory. New Directions for Adult and Continuing Education, 89, (3-14. doi: $10.1002 /$ ace. 3

Mezirow, J., (2000). Learning to think like adult: Core concepts of transformation theory. In J. Mezirow and Associates (Eds.), Learning as transformation: Critical perspectives on a theory in progress (pp. 3-33). San Francisco, CA: Jossey-Bass.

Mezirow, J. (1990).Fostering Critical Reflecting in Adulthood, San Francisco: JosseyBass.

McNair, S., \& Watts, J. (2014). At the crossroads: the case for mid-life career review. Adults Learning, 25(3), 16-19.

Miller, L., \& Cable, C. (Eds.), (2008). Professionalism in the early years. London: Oxon Hodder Education.

Nelken, M. L. (2009), Negotiating Classroom Process: Lessons from Adult Learning. Negotiation Journal, 25(2), 181-194. doi:10.1111/j.1571-9979.2009.00219.x

Peeters, J., De Backer, F., Buffel, T., \& Lombaerts, K. (2014). Adult Learners' Informal Learning Experiences in Formal Education Setting. Journal of Adult Development, 21(3), 181-192. doi:10.1007/s10804-014-9190-1

Pendergast, D., Garvis, S., \& Keogh, J., (2011). Pre-service student-teacher self-efficacy beliefs: An insight into the making of teachers. Australian Journal of Teacher Education, 36(12), 46-58. (12). doi:10.14221/ajte.2011v36n12.6

Pietarinen, J., Pyhältö, K., Soini, T., \& Salmela-Aro, K. (2013) Reducing teacher burnout: A socio-contextual approach. Teaching and Teacher Education, 35, 62-72. doi:10.1016/j.tate.2013.05.003

Pyhältö, K., Pietarinen, J., \& Soini, T. (2015). Teachers' professional agency and learning - From adaptation to active modification in the teacher community. Teachers and Teaching: Theory and Practice, 21(6), 811-830. doi: 10.1016/j.tate.2013.05.003

Quedler, E., \& Lamb, M. (2016). Learning as a lifelong process - meeting the challenges of the changing employability landscape: competences, skills and knowledge for sustainable development. International Journal of Continuing Engineering Education and Life Long Learning, 26 (3), 273-293. https:// doi.org/10.1504/IJCEELL.2016.078447

Ross, A. L., Archer, L., Hutchings, M., Gilchrist, R., Thomson, D., John, C., \& Akantziliotou, C. (2002). Potential mature student recruitments to higher education. Research report. London.

Ryan, G. W., \& Bernard, H. R. (2000). Data Management and Analysis Methods. In N. Denzin, \& Y. Lincoln (Eds.), Handbook of Qualitative Research (pp. 769-802). Thousand Oaks: Sage.

Soini, T., Pietarinen, J., Toom, A., \& Pyhältö, K. (2015). What contributes to first year student teacher's sense of professional agency in the classroom? Teachers and Teaching: Theory and Practice, 21(6), 641-659. doi:10.1080/13540602.2015.1044326

Soini, T., Pietarinen, J., \& Pyhältö, K. (2016). What if teachers learn in the classroom? Teacher Development, 20(3), 380-397. doi: 10.1080/ 13664530. 2016.1149511

Soini, T., Pyhältö, K., \& Pietarinen, J. (2010). Pedagogical well-being: Reflecting learning and well-being in teachers' work. Teachers and Teaching: Theory and Practice, 16(6), 735-751. doi: 10.1080/13540602.2010.517690

Spear, M., Gould, K., \& Lee, B. (2000). Who would be a teacher? A review of factors motivating and demotivating prospective and practising teachers. Slough: NFER. 
Toom, A., Pietarinen, J. Soini, T., \& Pyhältö, K. (2017). How does the learning environment in teacher education cultivate first year student teachers' sense of professional agency in the professional community? Teaching and teacher education, 63, 126-136. doi:10.1016/j.tate.2016.12.013

Turnbull, M. (2005). Student teacher professional agency in the practicum, Asia-Pacific Journal of Teacher Education, 33(2), 195-208. doi: 10.1080/13598660500122116

Ukkonen-Mikkola, T., \& Turtiainen, H. (2016). Learning at work in the boundary space of education and working life [Työssäoppiminen koulutuksen ja työelämän rajavyöhykkeellä]. Journal of early childhood education research, 5(1), 44-68, http://jecer.org/fi/wp-content/uploads/2016/02/Ukkonen-MikkolaTurtiainenissue5-1.pdf

Urban, M. (2008). Dealing with uncertainty: Challenges and possibilities for the early childhood profession. European Early Childhood Education Research Journal, 16(2), 135-152. doi:10.1080/13598660500122116

Vähäsantanen, K., Hökkä, P., Paloniemi, S., Herranen, S., \& Eteläpelto, A. (2017). Professional learning and agency in an identity coaching programme. Professional Development in Education, 43(4), 514-536. doi: 10.1080/19415257.2016.1231131

Vähäsantanen, K., Saarinen, J., \& Eteläpelto, A. (2009). Between school and working life: Vocational teachers' agency in boundary-crossing settings. International Journal of Educational Research, 48(6), 395-404. doi:10.1016/j.ijer.2010.04.003

Väisänen S., Pietarinen, J. Pyhältö, K., Toom, A. \& Soini, T. (2018). Student teachers' proactive strategies and experienced learning environment for reducing studyrelated burnout. Journal of Education and Learning, 7(1), doi:10.5539/jel.v7n1p208. 